Vol.46, n. 4 : pp. 507-514, December 2003 ISSN 1516-8913 Printed in Brazil
BRAZILIAN ARCHIVES OF BIOLOGY AND TECHNOLOGY

AN INTERNATIONAL JOURNAL

\title{
Variation and Its Distribution in Wild Cacao Populations from the Brazilian Amazon
}

\author{
Luiz Antônio dos Santos Dias ${ }^{1 *}$, Júlio Pontes Barriga ${ }^{2}$, Paulo Yoshio Kageyama ${ }^{3}$ and Caio \\ Márcio Vasconcellos Cordeiro de Almeida ${ }^{4}$ \\ ${ }^{1}$ Departamento de Biologia Geral/BIOAGRO; Universidade Federal de Viçosa; 36571-000; Viçosa - MG - Brazil. \\ ${ }^{2}$ Delegacia Federal de Agricultura do Maranhão (DFA/MA); 65020-500; São Luís - MA - Brazil. ${ }^{3}$ Departamento \\ de Ciências Florestais; Escola Superior de Agricultura "Luiz de Queiroz"; Universidade de São Paulo; C. P. 09; \\ 13418-900; Piracicaba-SP - Brazil. ${ }^{4}$ CEPLAC/SUPOC/SERPE; Av. Gov. Jorge Teixeira, 86; Nova Porto Velho; \\ 78904-300; Porto Velho - RO - Brazil
}

\begin{abstract}
A sample of 64 progenies (320 cacao trees as a whole) from four Brazilian Amazon basins was collected and evaluated on the basis of 15 fruit and seed traits. Nested univariate analyses of variance showed significant variation across progenies and basins. However, most of the variability appeared to be due to among trees and basins differences. The multivariate analysis showed that the differentiation in cacao populations occurred among basins. Since cacao diversity was predominantly found in trees within basins and among basins, one should optimize the collecting process by taking as many trees as possible starting from few progenies and many river basins. These findings seemed to validate gene conservation efforts made to date to preserve the cacao genetic resources and provide insight into the cacao genetic structure aiming cacao collection, management and improvement.
\end{abstract}

Key words: Theobroma cacao L., cacao trees, genetic structure, collecting wild germplasm, Amazon river basin

\section{INTRODUCTION}

The cacao tree, Theobroma cacao L., is an insectpollinated mixed perennial species, domesticated by the Mayas, thousands of years ago (Dias, 2001a). Originally cultivated trees belonged to the Criollo racial group (Theobroma cacao var. cacao). 'Non-Criollo' groups of cacao trees exist in their wild state in South America in the Amazon basin, and they constitute the Amazon Forastero racial group (Theobroma cacao var. sphaerocarpum). Amazon Forasteros have been cultivated only during the last two or three centuries (Cheesman, 1944; Cuatrecasas, 1964).
Presently, this racial group accounts for over $80 \%$ of the world's production of cacao. Both Criollos and Forasteros are distinguished basically by fruit and seed characteristics. Trinitario is a hybrid group between the two, developed from the natural hybridization that took place in Trinidad, when the Criollo plantations were ravaged by disease in the mid-18th century and the lost trees were replaced by Forastero, interplanted with the remaining Criollo (Cheesman, 1944).

The putative cacao centre of origin is believed to be in the upper waters of the Amazon tributaries Napo, Putumayo (Iça River in Brazil) and Caquetá (Japurá River in Brazil) at the foot of the Andes

* Author for correspondence 
(Cheesman, 1944), currently border of Colombia and Ecuador. From this region, cacao dispersed throughout the Northern and Southern regions having the Andean Cordillera working as the barrier that allowed the differentiation between Criollos and Forasteros. One can find Criollo populations from Central America to Northern South America. Amazon Forastero populations are from the Lower and Upper Amazon. In other words, Criollos are confined to the pacific western slope while Forasteros are found in the Amazon basin in the Guyanas, Surinam and Venezuela. After revisiting in depth all the hypotheses existents, Dias (2001b) proposed a new scenery for the origin and dispersal of cacao based on paleogeological, anthropological and historical evidences and, studies of population genetics made with molecular markers.

The Brazilian Amazon region constitutes one of the most extensive reserves of cacao genetic variability. In this region, expressive variability regarding plant vigor, yield and its components, resistance to witches' broom disease, size and leaf coloration, and fruit and seed characteristics has been found (Barriga et al., 1985; Almeida et al., 1987; Almeida and Almeida, 1987; Bartley et al., 1988; Almeida and Dias, 2001). In an effort to preserve cacao genetic resources and to broaden the crop genetic basis, the Executive Commission for Planning Cacao Culture (CEPLAC) - the institution that is responsible for the cacao Brazilian research - has collected and incorporated into their germplasm banks more than 2,000 accessions since 1965 (Barriga et al., 1985; Almeida et al., 1987; Almeida and Almeida, 1987; Almeida et al., 1995). Despite the great importance of this work, at the moment, the ransomed variability represents only a small sample of the overall variability of the species. On the other hand, wild populations are under eminent risk of extinction due to deforestation, developmental activities such as wood and mineral exploitations, large hydroelectric projects and by the expansion of the agricultural frontier. For instance, in the last 20 years, approximately 550 thousand $\mathrm{km}^{2}(14 \%)$ of the Amazon forest were cleared. Therefore, it is imperative that the cacao genepool be collected, conserved and studied for the present and future. In fact, cacao has been considered by the International Board for Plant Genetic Resources (IBPGR, 1981) as a priority crop for conservation. However, there are few studies about the levels of genetic variation maintained within wild populations and about the way this variation is geographically distributed.

To manage the cacao genetic resources efficiently, we must know how genetic variation is distributed and what factors influence its distribution. There is some evidence that the cacao distribution is discontinuous, with presence of small populations confined in the vicinity of the riverbanks along the alluvial plains (Bartley, unpublished work). Knowledge about the level and the spatial distribution of the variability will provide a scientific basis for the collection and conservation of cacao germplasm. In the case of the diversity to be concentrated in river basins this information will be used to optimize the collection of germplasm for gene conservation programs. The role of rivers in the diversification of Amazonian biota was already recognized by Alfred Russel Wallace in the 1840s (Wallace, 1889). Pound (1938) and Almeida et al. (1987) described differentiation of cacao populations by river basins; however, this hypothesis has never been investigated. The goals of this study, using morphological data available from four river basins (see Table 1 and Fig. 1), were: $i$ ) to assess the diversity and its distribution pattern within and among cacao populations from the Brazilian Amazonia; ii) to evaluate the hypothesis of differentiation among them by basins and; iii) to examine the cacao collection strategy carried out by CEPLAC.

Table 1 - Details of basins studied

\begin{tabular}{lllccc}
\hline Basins & Range of latitude & Range of longitude & $\begin{array}{c}\text { Mean } \\
\text { altitude (m) }\end{array}$ & $\begin{array}{c}\text { Range of annual } \\
\text { rainfall (mm) }\end{array}$ & $\begin{array}{c}\text { Year of } \\
\text { collecting }\end{array}$ \\
\hline Japurá & $01^{0} 25^{\prime}-02^{0} 42^{\prime} \mathrm{S}$ & $64^{0} 28^{\prime}-69^{0} 56^{\prime} \mathrm{W}$ & 80 & $2650-3650$ & 1983 \\
Amazon & $02^{0} 38^{\prime}-03^{0} 08^{\prime} \mathrm{S}$ & $56^{0} 44^{\prime}-58^{0} 18^{\prime} \mathrm{W}$ & 50 & $>2000$ & 1987 \\
Purus & $07^{0} 48^{\prime}-09^{0} 03^{\prime} \mathrm{S}$ & $67^{0} 06^{\prime}-68^{0} 41^{\prime} \mathrm{W}$ & 125 & $1750-2250$ & 1981 \\
Ji-Paraná & $11^{0} 02^{\prime}-11^{0} 11^{\prime} \mathrm{S}$ & $61^{0} 52^{\prime}-62^{0} 39^{\prime} \mathrm{W}$ & 300 & $1500-2300$ & 1984 \\
\hline
\end{tabular}




\section{MATERIALS AND METHODS}

Plant material: The present study was carried out in the Cacao Genetic Resources Station "José Haroldo" germplasm bank (ERJOH). The ERJOH is located in Marituba, Pará State, Brasil (lat $10^{\circ}$ $12^{\prime} \mathrm{S}$, long $48^{0} 13^{\prime} \mathrm{W}$, altitude $12 \mathrm{~m}$ ), $18 \mathrm{~km}$ away from Belém, the capital of the State. For the present work, a total of 320 cacao trees from four river basins (Table 1 and Fig. 1), representing a considerable part of the river basin diversity of the Brazilian Amazon region, were sampled and measured for fruit and seed traits. It was assumed that four basins, which were randomly chosen, were a representative sample out of the river basins existing in the Amazon region. Within each basin, 16 open-pollinated progenies were sampled, with five trees/progeny being evaluated.

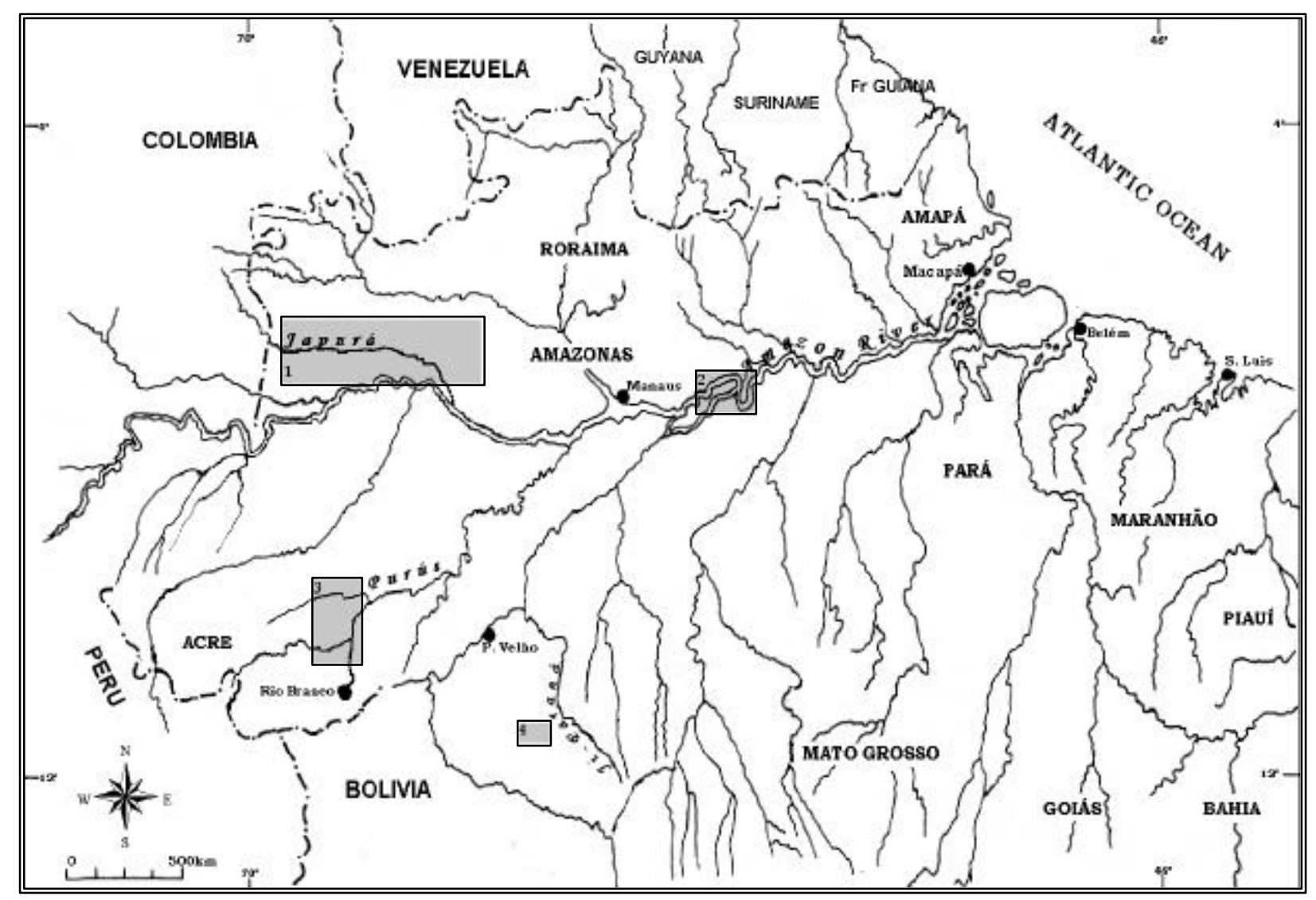

Figure 1 - Map of Brazilian Amazonian region, showing the four basins cacao tree collection (1. Japurá, 2. Amazon, 3. Purus and 4. Ji-Paraná).

For fruit descriptors, random samples of five fruits/tree were collected and the following traits were measured: shape (SP), basal constriction (BC), apex form (AF), length (LG), width (WD), length/width ratio (LG/WD), weight (WG), fruit surface rugosity (FS), ridge pair appearance (RP), primary furrow depth (PF), wall thickness (WT), and seed number/fruit (NS). To analyze seed descriptors, the seeds from the same five fruits were extracted, peeled, and counted and their wet weight (WW), dry weight (DW), and form (SF) measured. The characterization occurred during
January 1993. The procedures followed for the characterization were as detailed by Engels et al. (1980).

Description of basins: Aiming at the collection of cacao germplasm, Almeida et al. (1987) divided the Brazilian Amazon region into basins (186), classified as follows: 4 of first order, 60 of second order and 122 of third order. Four basins (see Fig. 1 and Table 1) randomly sampled were partially studied: one of first order (middle Amazon River basin), two of second order (Purus 
and Japurá River basins), and one of third order (Ji-Paraná River basin). Details such as where, when and by whom a particular progeny from each river basin was collected could be found elsewhere (Almeida et al., 1995).

The samples taken represented traditional cacao crop regions (Amazon) and regions where cacao grew spontaneously (Purus and Japurá); regions subject to flooding (Purús, Japurá and Amazon) and non-flooded regions (Ji-Paraná); regions from different geographical positions as central (Amazon), north (Japurá) and south (Purús and JiParaná); the region comprising the putative cacao centre of origin (Japurá); the region which appears to indicate some human intervention in the cacao spread (Ji-Paraná); and the region in which cacao trees have low or no symptoms of witches' broom disease.

Statistical methods: Two methods were used to determine the differentiation in morphological traits: nested univariate analyses of variance and multivariate analysis. The univariate approach calculates variance components at each of three levels of population subdivision: among basins $\left[\mathrm{B}_{\mathrm{i}}\right]$, among progenies within basins $\left[\mathrm{P}_{\mathrm{j}(\mathrm{i})}\right]$, and among trees within progenies within basins $\left[\mathrm{T}_{\mathrm{k}(\mathrm{ij})}\right]$. The random effects $B_{i}, P_{j(i)}, T_{k(i j)}$ were assumed independent, with means equal to 0 and variances equal to $\sigma_{\mathrm{b}}^{2}, \sigma_{\mathrm{p}}^{2}, \sigma_{\mathrm{t}}^{2}$, respectively. Then, the total variance estimate $\sigma_{\mathrm{T}}^{2}$ was partitioned as follows: $\sigma_{\mathrm{T}}^{2}=\sigma_{\mathrm{b}}^{2}+\sigma_{\mathrm{p}}^{2}+\sigma_{\mathrm{t}}^{2}$

The nested analyses of variance were performed using the following model:

$\mathrm{Y}_{\mathrm{ijk}}=\mu+\mathrm{B}_{\mathrm{i}}+\mathrm{P}_{\mathrm{j}(\mathrm{i})}+\mathrm{T}_{\mathrm{k}(\mathrm{ij})}$ where

$\mathrm{Y}_{\mathrm{ijk}}=$ average value of the trait $\mathrm{Y}$ measured on five fruits in the $\mathrm{k}^{\text {th }}$ tree of the $\mathrm{j}^{\text {th }}$ progeny in the $\mathrm{i}^{\text {th }}$ basin;

$\mu$ = overall mean;

$\mathrm{B}_{\mathrm{i}}=$ effect of the $\mathrm{i}^{\text {th }}$ basin; $i \mathrm{i}=1,2, \ldots, 4$;

$\mathrm{P}_{\mathrm{j}(\mathrm{i})}=$ effect of the $\mathrm{j}^{\text {th }}$ progeny in the $\mathrm{i}^{\text {th }}$ basin; $\mathrm{j}=1,2, \ldots, 16$;

$T_{k(j)}=$ random error defined by the effect of the $k^{\text {th }}$ tree of the $\mathrm{j}^{\text {th }}$ progeny in the $\mathrm{i}^{\text {th }}$ basin; $\mathrm{k}=1,2, \ldots$, 5 .

The format of the nested univariate analyses of variance and the expectation mean squares are shown in Table 2. The multivariate approach to describe differentiation between basins was based on the $\mathrm{D}^{2}$-statistic of distance of Mahalanobis (1936). It is the most robust measurement of distance, with the property of being scale invariant and, therefore, it is dimensionless (Dias and Kageyama, 1998). The $\mathrm{D}^{2}$ distance between two basins $i$ and $i$ ' on $p$ characters is defined as:

$\mathrm{D}^{2}=\mathrm{d}_{\sim} \mathrm{W}^{-1} \mathrm{~d}$

where $d$ is a vector of differences between the basins averages $i$ and $i$ ' for all $p$ characters and $\mathrm{d}^{\prime}$ is its transpose. $\mathrm{W}$ is the $p \times p$ within-basin covariance matrix.

In order to achieve $\mathrm{D}^{2}$ values significance levels, $\mathrm{F}$ statistics was applied. All the statistical analyses were performed using the SAS package (SAS Institute Inc., 1989). The univariate analyses of variance and the $\mathrm{D}^{2}$ Mahalanobis distance were performed by using the NESTED and CANDISC procedures, respectively, from SAS.

Table 2 - Format of nested analysis of variance and the expectation mean squares

\begin{tabular}{lllcc}
\hline Sources of variation & \multicolumn{1}{c}{ d. f. } & Expected mean squares & Entry & Test against entry \\
\hline Basins (B) & $(\mathrm{a}-1)$ & $\sigma_{\mathrm{t}}^{2}+\mathrm{n} \sigma_{\mathrm{p}}^{2}+\mathrm{np} \sigma_{\mathrm{b}}^{2}$ & 1 & 2 \\
Progenies (P) within (B) & $\mathrm{a}(\mathrm{b}-1)$ & $\sigma_{\mathrm{t}}^{2}+\mathrm{n} \sigma_{\mathrm{p}}^{2}$ & 2 & 3 \\
Trees (T) within (P) & $\mathrm{ab}(\mathrm{c}-1)$ & $\sigma_{\mathrm{t}}^{2}$ & 3 & \\
\hline Total & $\mathrm{abc}-1$ & & & \\
\hline
\end{tabular}

\section{RESULTS AND DISCUSSION}

For all morphological traits studied, highly significant differences across progenies and basins were revealed (Table 3). In most cases, the progeny component of variance was rather low for all traits. For seven of the fruit traits, the tree variance component was higher. Conversely, for seven other traits concerning the seeds and the fruit shape such as LG/WD, FS, WT and NS, the 
basin variance component was higher. In general, the partitioning of variation within and among populations (river basins) revealed that most variation was detected within populations, as in other studies with cacao tree, involving isozymatic (Ronning and Schnell, 1994; Sounigo et al., 1997) and RAPD (Russel et al., 1993) markers. Many other tree species have revealed the same pattern of variation distribution. Tropical trees showed high levels of genetic variation, contained mostly within the populations (Dias and Kageyama, 1991).

$\mathrm{D}^{2}$ values computed for differentiation between basins (Table 4) ranged from 4.9 to 26.6. Japurá and Ji-Paraná basins showed to be the most divergence, while Purus and Amazon were the most similar basins. Considering Cheesman's (1944) hypothesis, the Japurá River (Caquetá River in Colombia) basin comprised the putative cacao centre of origin which could explain its relative greatest divergence. When submitted to $\mathrm{F}$ statistic, all $\mathrm{D}^{2}$ values were highly significant agreeing with results found by the previous univariate test. Consequently, each basin was genetically distinct from each other.

Table 3 - Summary of the nested analysis of variance and the variance components (in \%) for each source of variation

\begin{tabular}{|c|c|c|c|c|c|c|c|}
\hline & \multirow[b]{3}{*}{ Traits } & \multicolumn{6}{|c|}{ Sources of variation } \\
\hline & & \multicolumn{2}{|c|}{ Basins (B) } & \multicolumn{2}{|c|}{ Progenies (P) within (B) } & \multicolumn{2}{|c|}{ Trees $(\mathrm{T})$ within $(\mathbf{P})$} \\
\hline & & $\begin{array}{c}\text { Mean } \\
\text { Squares }\end{array}$ & $\begin{array}{c}\text { Variance } \\
\text { Component } \\
(\%)^{2}\end{array}$ & $\begin{array}{c}\text { Mean } \\
\text { Squares }\end{array}$ & $\begin{array}{c}\text { Variance } \\
\text { Component } \\
(\%)\end{array}$ & $\begin{array}{c}\text { Mean } \\
\text { Squares }\end{array}$ & $\begin{array}{c}\text { Variance } \\
\text { Component } \\
(\%)\end{array}$ \\
\hline \multirow[t]{12}{*}{ Fruit } & $\mathrm{SP}^{1}$ & $0.334 * *$ & 9.38 & $0.063 * *$ & 21.37 & 0.025 & 69.25 \\
\hline & $\mathrm{BC}$ & $1.348 * *$ & 25.41 & $0.078 * *$ & 12.75 & 0.039 & 61.84 \\
\hline & $\mathrm{AF}$ & $1.644 * *$ & 24.44 & $0.170 * *$ & 37.81 & 0.028 & 37.75 \\
\hline & LG & $1.441 * *$ & 25.07 & $0.125^{* *}$ & 29.02 & 0.030 & 45.90 \\
\hline & WD & $0.059 * *$ & 2.97 & $0.030 * *$ & 36.76 & 0.007 & 60.26 \\
\hline & LG/WD ${ }^{\mathrm{a}}$ & $1.144 * *$ & 64.78 & $0.012 * *$ & 5.86 & 0.006 & 29.36 \\
\hline & WG & $165.154 * *$ & 38.76 & $6.133 * *$ & 14.59 & 2.391 & 46.64 \\
\hline & FS & $35.442 * *$ & 62.58 & $0.504 * *$ & 8.71 & 0.200 & 28.70 \\
\hline & $\mathrm{RP}$ & 0.007 & 0.00 & $0.110 * *$ & 38.67 & 0.026 & 61.33 \\
\hline & $\mathrm{PF}$ & $553.213 * *$ & 17.70 & $45.708 * *$ & 11.32 & 25.431 & 70.98 \\
\hline & WT & $2.341 * *$ & 62.15 & $0.036 * *$ & 10.36 & 0.012 & 27.48 \\
\hline & NS & $0.757 * *$ & 43.95 & $0.027 * *$ & 18.90 & 0.007 & 37.15 \\
\hline \multirow[t]{3}{*}{ Seed } & WW & $0.650 * *$ & 47.10 & $0.016 * *$ & 10.55 & 0.007 & 42.35 \\
\hline & DW & $89.232 * *$ & 64.53 & $1.425^{* *}$ & 12.09 & 0.397 & 23.37 \\
\hline & SF & $44.092 * *$ & 67.35 & $0.623 * *$ & 11.15 & 0.173 & 21.50 \\
\hline d.f. & & 3 & & 60 & & 256 & \\
\hline
\end{tabular}

Table 4. Mahalanobis distance (above diagonal) to river basins and $\mathrm{P}$ values by $\mathrm{F}$ statistic (bellow diagonal)

\begin{tabular}{lcccc}
\hline River basins & Japurá & Amazon & Purus & Ji-Paraná \\
\hline Japurá & 0 & 8.2658 & 12.6837 & 26.6623 \\
Amazon & 0.0001 & 0 & 4.9548 & 14.0855 \\
Purus & 0.0001 & 0.0001 & 0 & 8.6841 \\
Ji-Paraná & 0.0001 & 0.0001 & 0.0001 & 0 \\
\hline
\end{tabular}

This result appeared to confirm that the differentiation of cacao wild populations from the Brazilian Amazon region evolved according to the each river basin system.
Although we would not be able to distinguish the several hypotheses for this cacao populations spatial differentiation pattern based on river basins, it is possible to discuss them. In fact, it may be correlated with the large distance among 
the studied populations or may reflect the action of past evolutionary processes. In the first case, the isolation among the four populations, all more than $800 \mathrm{~km}$ apart, prevented the gene flow among them. In the second case, such pattern of differentiation could be achieved by the combination of the Riverine barriers (Patton et al., 1994), Refuge (Haffer, 1969) and the Amazon Lagoon (Klammer, 1984) hypotheses. According to the Riverine barriers hypothesis, the development of the Amazon River system, caused by Cenozoic uplift of the Andes, promoted a series of vicariance events. As a consequence, the fragmentation of ranges of widespread ancestral species occupying that region took place. Demes at opposite margins or at basins have the gene flow reduced, with natural selection and genetic drift as main driving forces of divergence between populations. Hence, the intrabasin differentiation among populations is less pronounced than the interbasin differentiation. In addition, the gene flow is expected to be more restricted across large Rivers and across their mouths than across small ones and their headwaters. Unfortunately, the proof for this hypothesis would be the study of differentiation among cacao populations on adjacent rivers, which was not done here. However, the fact of each basin to be genetically distinct from each other, as revealed by applying the $\mathrm{D}^{2}$ statistic, proved that exchanges of fruits between far upstream and far downstream from the Japurá, Purus and Ji-Paraná basins for middle Amazon basin did not exist or it was inexpressive. The Refuge hypothesis is based on cycles of Pleistocene climatic changes, which resulted in corresponding cycles of fragmentation and coalescence of tropical forest species. Populations or entire communities, isolated in refuges, evolved independently under natural selection and genetic drift. Both hypotheses described above account for the classical allopatric speciation model. In some extension, the river basins studied (see Fig. 1) correspond with the refuge areas proposed by Prance (1973) for four families of trees, as follows: Japurá, Amazon, Purús, and Ji-Paraná basins with Imerí, Manaus, Tefé and Aripuanã refuges, respectively. Refuges areas have played an important role in the evolution of wild cacao populations from French Guyana, as argued by Lachenaud (1997).

Although the Amazon Lagoon hypothesis has been restricted to geology, it also could play an important role in the Neotropical diversification
(Marroig and Cerqueira, 1997). During the last four million years (4 Myr Before Present), in the Plio-Pleistocene, the rising level of sea became a barrier for the discharge of the Amazon water system, leading to formation of the Amazon Lagoon. The recurrent oscillation in the sea level for as long as 2 Myr B.P. resulted in a displacement of forest areas to the bordering of the present Amazon highlands. Thus, the differentiation occurred at highlands of basin borders increased for the isolation effect of enlarged Rivers.

In turn, the extent of genetic differentiation between and within river basins at a given spatial scale depends on the distance and magnitude of gene flow, the scale of natural selection and, the genetic drift. Cacao trees present some specialization in their pollination mode. In terms of management, the knowledge of pollinator population becomes as important as the knowledge about the tree species serviced by pollinators. Unfortunately, we know virtually nothing about this subject. Pollination is mainly achieved by a number of species of midges of the genus Forcipomya and, accidentally, for other insects (Chapman and Soria, 1983). Interestingly, these midges are so small that they are difficult to see and to study. Moreover, they fly from one tree to another foraging a short distance, frequently no more than $60 \mathrm{~m}$ (Posnette, 1950). Hence, pollen flow occurs among neighboring trees causing the formation of family clusters. In studying the relationship between the distribution of genetic variation within and between tropical tree species and the gene flow via pollen, Loveless and Hamrick (1987) argued that the smaller flight distance of pollinators the larger genetic variation between population. This statement can be directly applicable to cacao germplasm differentiation by basin. Restricted gene flow and within-basin differentiation due to microsite selection pressure increases the formation of neighbourhoods. Restricted gene flow also reduces effective population size, causing increase of genetic drift and of inbreeding due to mating among relatives. Furthermore, even having complete and hermaphrodite flower, an incompatibility system operates in the cacao species (Cope, 1962), favouring outcrossing, without excluding selfpollination. Within the same population some cacao trees may be entirely self-incompatible, while others may display self-compatibility to varying degrees. Thus, cacao trees with different 
outcrossing behaviours compete within each population.

\section{CONCLUSIONS}

The present study provides insight into cacao genetic structure aiming at cacao collection, management and improvement, i.e., the river basin appears to be an important factor in variation structuring of cacao populations from the Amazonia. Nevertheless, it is necessary to be cautious since characterization has been done within one year only. Thus, this insight could be influenced by the effect of genotype-year interaction.

An adequate collecting strategy must take into account the spatial distribution of the genetic variation. Because cacao diversity is predominantly concentrated in trees within basins and among basins, taking as many as possible trees for few progenies from many basins one should optimize the collecting process. Moreover, the little understanding of the organizing genetic structure of the cacao wild populations requires the collecting of larger samples.

\section{RESUMO}

O nível e a distribuição da variação em populações silvestres de cacau é pouco conhecido. Para a sua avaliação coletaram-se, em quatro bacias hidrográficas, 64 progênies (320 cacaueiros), as quais foram avaliadas para 15 características de fruto e semente. Análises univariadas de variância evidenciaram significante variação entre progênies e bacias. A análise multivariada revelou que a diferenciação entre as populações está estruturada por bacias. Uma vez que a maior parte da variação concentrou-se entre cacaueiros dentro de bacias e entre bacias, para se otimizar o processo de coleta de germoplasma deve-se coletar muitos cacaueiros procedentes de poucas progênies e muitas bacias. Esses resultados validam os esforços de coleta de germoplasma feitos até o presente para preservar os recursos genéticos de cacau e fornecem subsídios para o entendimento da estrutura genética visando a coleta, o manejo e o melhoramento do cacaueiro.

\section{REFERENCES}

Almeida, C. M. V. C. and Almeida, C. F. G. (1987), Coleta de cacau silvestre no Estado de Rondônia. Rev. Theobroma, 17, 65-92.

Almeida, C. M. V. C.; Barriga, J. P.; Machado, P. F. R. and Bartley, B. G. D. (1987), Evolução do programa de conservação dos recursos genéticos de cacau na Amazônia brasileira. Boletim Técnico, 5 (CEPLAC/DEPEA, Belém).

Almeida, C. M. V. C.; Machado, P. F. R.; Barriga, J. P. and Silva F. C. O. (1995), Coleta de cacau (Theobroma cacao L.) da Amazônia brasileira: uma abordagem histórica e analítica. Porto Velho : CEPLAC/PLANAFLORO.

Almeida, C. M. V. C. and Dias, L. A. S. (2001), Recursos genéticos. In: Dias, L. A. S. (Ed.). Melhoramento genético do cacaueiro. Viçosa : FUNAPE. pp. 163-216.

Barriga, J. P.; Machado, P. F. R.; Almeida, C. M. V. C. and Almeida, C. F. G. (1985), A preservação e utilização dos recursos genéticos de cacau na Amazônia Brasileira. In: $9^{\text {th }}$ Intl. Cocoa Res. Conf. London : Cocoa Producers' Alliance. pp. 73-79.

Bartley, B. G. D.; Machado, P. F. R.; Ahnert, D. and Barriga, J. P. and Almeida, C. M. V. C. (1988), Descrição de populações de cacau da Amazônia brasileira. I - observações preliminares sobre populações de Alenquer, Pará. In: $10^{\text {th }}$ Intl. Cocoa Res. Conf. London : Cocoa Producers' Alliance. pp. 665-672.

Chapman, R. K. and Soria, S. J. (1983), Comparative Forcipomyia (Diptera, Ceratopogonidae) pollination of cacao in Central America and Southern Mexico. Rev. Theobroma, 13, 129-139.

Cheesman, E. E. (1944), Notes on the nomenclature, classification and possible relationships of cacao populations. Trop. Agric., 21, 144-159

Cope, F. W. (1962), The mechanism of pollen incompatibility in Theobroma cacao L. Heredity, 17, 157-182.

Cuatrecasas, J. (1964), Cacao and its allies: a taxonomic revision of the genus Theobroma. Contrib. US Nat. Herb., 35, 377-605.

Dias, L. A. S. (2001a), Melhoramento genético do cacaueiro. Viçosa : FUNAPE.

Dias, L. A. S. (2001b), Origem e dispersão de Theobroma cacao L.: novo cenário. In: Melhoramento genético do cacaueiro. Viçosa : FUNAPE. pp. 81-127.

Dias, L. A. S. and Kageyama, P. Y. (1991), Variação genética em espécies arbóreas e consequiências para o melhoramento florestal. Agrotrópica, 3, 119-127.

Dias, L. A. S. and Kageyama, P. Y. (1998), Comparison between multivariate methods applied for the evaluation of genetic divergence in cacao (Theobroma cacao L.). Braz. Arch. Biol. Technol., 41, 199-206. 
Engels, J. M. M.; Bartley, B. G. D.; Enríquez, G. A. (1980), Cacao descriptors, their states and modus operandi. Turrialba, 30, 209-218.

Haffer, J. (1969), Speciation in Amazonian forest birds. Science, 165, 131-137.

IBPGR (1981), Genetic resources of cocoa. Rome : IBPGR.

Klammer, G. (1984), The relief of the extra-Andean Amazon basin. In: Sioli, H. and Junk, W. (Eds.). The Amazon: Limnology and landscape ecology of a mighty tropical river and its basin. pp. 47-83.

Lachenaud, P. (1997), Genetic/taxonomic structuring of the Theobroma cacao L. species - fresh hypotheses. INGENIC Newsletter, 3, 10-11.

Loveless, M. D. and Hamrich, J. L. (1987), Distribución de la variación en espécies de arboles tropicales. Rev. Biol. Tropical, 35, 165-175.

Mahalanobis, P. C. (1936), On the generalized distance in statistics. Proc. Nat. Inst. Sci. India, 12, 49-55.

Marroig, G. and Cerqueira, R. (1997), Plio-Pleistocene South America history and the Amazonas Lagoon hypothesis: a piece in the puzzle of Amazonian diversification. J. Comp. Biol., 2, 103-119.

Patton, J. L.; Silva, M. N. F. and Malcolm, J. R. (1994), Gene genealogy and differentiation among arboreal spiny rats (Rodontia: Echimydae) of the Amazon basin: a test of the riverine barrier hypothesis. Evolution, 48, 1314-1323.

Posnette, A. F. (1950), The pollination of cacao in the Gold Coast. J. Hort. Sci., 25, 155-163.

Pound, F. J. (1938), Cacao and witcbroom disease (Marasmius perniciosus) of South America with notes on other species of Theobroma: report on a visit to Ecuador, the Amazon valley and Colombia April 1937-April 1938. Yuille's Printerie, Trinidad and Tobago.
Prance, G. T. (1973), Phytogeographic support for the theory of Pleistocene forest refuges in the Amazon basin, based on evidence from distribution patterns in Caryocaraceae, Chrysobalanaceae, ichapetalaceae and Lecythidaceae. Acta Amazonica, 3, 5-26.

Ronning, C. M. and Schnell, R. J. (1994), Allozyme diversity in a germplasm collection of Theobroma cacao L.. The J. of Heredity, 85, 291-295.

Russel, J. R.; Hosein, F.; Johnson, E.; Waugh, R. and Powell, W. (1993), Genetic differentiation of cocoa (Theobroma cacao L.). Mol. Ecol., 2, 89-97.

SAS Institute Inc. (1989), SAS/STAT user's guide, version 6. 4. ed. Cary : SAS Institute. vol. 2.

Sounigo, O.; Umaharan, R. and Sankar, A. (1997), Assessing genetic diversity in the International Cocoa Genebank of Trinidad (ICG,T) using isozyme electroforesis. INGENIC Newsletter, 3, 11-16.

Wallace, A. R. (1889), A narrative of travels on the Amazon and rio Negro. New York : Dover Publications.

Received: November 19, 2001; Revised: July 18, 2002; Accepted: November 01, 2002. 